\title{
Protective role of quercetin against manganese-induced injury in the liver, kidney, and lung; and hematological parameters in acute and subchronic rat models [Retraction]
}

\author{
Bahar E, Lee G-H, Bhattarai KR, et al. Drug Des Dev \\ Ther. 2017;11:2605-2619.
}

The Editor-in-Chief and Publisher of Drug Design, Development and Therapy wish to retract the published article.

Concerns were raised about the possibility of image duplication in the published article. Following a review, it was determined the article contained an unacceptable level of image duplication and the findings and conclusions in the presented study were no longer supported.

The affected figures within the present article are:

- Figure 5 image $\mathrm{Mn}, \mathrm{Mn}+\mathrm{Qct}_{25}$ and $\mathrm{Mn}+\mathrm{Qct}_{50}$

- Figure 6 image $\mathrm{Mn}, \mathrm{Mn}+\mathrm{Qct}_{25}$ and $\mathrm{Mn}+\mathrm{Qct}_{50}$

- Figure 9 image Kidney $\mathrm{Mn}+\mathrm{Qct}_{50}$ is the same presented in Figure 10 Kidney Mn + Qct $_{50}$
- Figure 9 Lung Control is the same presented in Figure 9 Lung $\mathrm{Mn}+\mathrm{Qct}_{25}, \mathrm{Mn}+\mathrm{Qct}_{50}$ and Figure 10 Lung Control

- Figure 9 Lung Mn in the same presented in Figure 10 Lung Mn + Qct $_{25}$

- Figure 11 Liver Control is the same presented in Figure 11 Liver $\mathrm{Mn}+\mathrm{Qct}_{50}$

- Figure 11 Kidney $\mathrm{Mn}+\mathrm{Qct}_{25}$ is the same as Figure 11 Kidney $\mathrm{Mn}+$ Qct $_{50}$

It was established the author Entaz Bahar acted alone in the image manipulation, however the remaining authors accept accountability for all aspects of the work as part of their publication agreement.

Our decision-making was informed by COPE's retraction guidelines. The authors cooperated throughout the process and agree with the decision to retract. The authors wish to apologize for this error. 


\section{Publish your work in this journal}

Drug Design, Development and Therapy is an international, peerreviewed open-access journal that spans the spectrum of drug design and development through to clinical applications. Clinical outcomes, patient safety, and programs for the development and effective, safe, and sustained use of medicines are a feature of the journal, which has also been accepted for indexing on PubMed Central. The manuscript management system is completely online and includes a very quick and fair peer-review system, which is all easy to use. Visit http://www. dovepress.com/testimonials.php to read real quotes from published authors.

Submit your manuscript here: https://www.dovepress.com/drug-design-development-and-therapy-journal 